\title{
The Metacognitive Strategies and Writing Competence of Grade 11 Students in a Philippine Public High School
}

\author{
Glory Ann L. Hacermida ${ }^{1}$ and Ivy G. Aboy ${ }^{2}$ \\ ${ }^{1}$ E.B. Magalona National High School, Negros Occidental, Philippines \\ ${ }^{2}$ University of Negros Occidental-Recoletos, Bacolod City, Philippines
}

\section{Article history:}

Submitted: 19 April 2021

Revised: 15 May 2021

Accepted: 15 June 2021

\section{Keywords:}

Education

Language learning

Metacognitive strategies

Writing competence

Descriptive-correlation

Philippines

\begin{abstract}
Metacognitive strategies are vital in enhancing students' writing competence, but local studies correlating them are limited. Thus, this descriptivecomparative and correlational study examined the use of the metacognitive strategies and the writing competence of 303 Grade 11 students of a public high school. Data gathered using a researcher-made survey questionnaire and a test revealed a moderate extent of use of the metacognitive strategies and an average writing competence. There is no significant difference in the extent of use of metacognitive strategies and level of writing competence in terms of gender and monthly income. However, there exists a difference in the parents' educational attainment and students' academic performance and a significant relationship between these variables. The conclusion has led to the recommendation for the Division of Negros Occidental to adopt the proposed syllabus for English for Academic and Professional Purposes.
\end{abstract}

\subsection{Introduction}

Writing competence is one of the essential abilities in the total development of an individual. With speaking, writing is considered a productive skill and is mainly used to communicate (Ozdemir \& Aydin, 2015). It enhances other skills such as controlling the learning process, using appropriate vocabulary, identifying errors, evaluating learning, thinking creatively, and improving language competence as a whole. To be at par with today's society's standards and build a personal identity, an individual must acquire these skills (Terogo et al., 2018).

For the Grade 11 Senior High School students of a national high school, writing is a productive task that serves as a self-expression tool and meets academic demands. However, most students display mediocre writing skills far below the instructional goal of developing excellent skills. Since writing is an intellectual skill, students tend to ignore monitoring how they accomplish the task and avoid this activity (Ungan, 2007; Tabak \& Topuzkanamis, 2014). Consequently, their written outputs become inadequate for global competitiveness.

In concurrence, many instructors consider writing as one of the most complicated skills to master. They have noticed that writing is a problem among students, even in their native language, and consequently in their second language (Nosratinia \& Adibifar, 2014). Learners who have difficulties in writing lack the necessary skills to use writing strategies, generate ideas, do little or no prewriting or planning, and revise a little because they consider it a waste of time (Harris et al., 2008; Alameddine \& Mirza, 2016). Moreover, they tend to have difficulties in vocabulary, poor knowledge and understanding of grammatical structure, and inability to sequence ideas logically and chronologically (Farroq, 2012; Quijano \& Legaspi, 2020).

The different learning styles of students and the strategies they employ could affect their learning outcomes. Competent writers qualitatively use their writing strategies; they tend to increase or decrease the use of their writing strategy depending on the nature and need of the writing task (Chien, 2007; Nosratinia \& Adibifar, 2014). As a result, to improve writing competence, researchers propose using writing strategies to address particular problems and help students become independent learners (Nguyen \& Gu, 2013).

Moreover, effective language strategies, especially the metacognitive strategies, have a facilitative function in internalizing, storing, retrieving, and acquiring a new language. In language teaching and learning, these strategies have been used to enhance communication skills, including writing (Chien, 2007; Nosratinia \& Adibifar, 2014). These are universal skills in which students lead, direct, manage, and control their learning (Nosratinia \& Adibifar, 2014). They help improve communication skills, language learning, reading comprehension, problem-solving skills, and even personality development (Rani \& Govil, 2013). 
Most international and local studies on metacognitive strategies link it with reading and listening; on the contrary, research focusing on its relationship with writing competence is scarce.

A few studies found that metacognitive writing strategies can improve writing performance and increase students' satisfaction. Moreover, it enhances students' awareness of learning to become self-regulated learners (Goctu, 2017). Also, awareness of cognition in pre, during, and post-writing through the metacognitive strategies help students regulate cognition when writing (Cer, 2019).

In this context, this study's primary concern is to explore the relationship between the extent of use of metacognitive strategies and the level of writing competence of Grade 11 students; thus, this study was conducted. This study aimed to describe and compare the extent of use of metacognitive strategies and the level of writing competence of the Grade 11 students of a selected national high school when taken as a whole and grouped according to sex, parents' educational attainment, family monthly income, and academic performance. Also, it sought to establish the correlation between metacognitive strategies and the level of writing competence. The findings of this study served as the basis for the creation of a syllabus for English for Academic and Professional Purposes (EAPP) that is designed to enrich students' written and oral communication skills.

\subsection{Framework of the Study}

This study was mainly anchored on two theories: The Theory of Language Learning Strategy by Rebecca Oxford and the Constructivist Theory by Jean Piaget.

This study theorizes that the use of metacognitive strategies enhances students' writing skills. Relatively, learners develop their language skills by connecting previous knowledge to new knowledge. This study also theorizes that personal variables such as sex, family monthly income, parents' educational attainment, and students' academic performance are factors that influence their extent of use of metacognitive strategies and their level of writing competence.

The Language Learning Strategy Theory by Oxford (1990) is grounded on the concept that using strategies helps individuals to effectively learn a language. It sprang out from a more general theory, the Second Language Acquisition Theory by Krashen (1981).

As one of the language learning strategies, metacognitive strategies refer to the overall skills within which students direct, conduct, supervise, and control how they acquire learning. The example manifestations are: designing for learning, reflecting about the learning process as it is occurring, observing one's understanding and judgment, and evaluating learning once the activity is accomplished. (Nosratinia \& Adibifar, 2014). The metacognitive strategies belong to indirect strategies. They present three parts: centering of learning, arranging and planning to learn, and evaluating learning.

Centering of learning aims to make students focus on what language skills they should master and what specific language activities they should perform. Arranging planning to learn involves controlling the writing process while writing the text. It also involves verifying one's progress in a global context such as content and organization and local features such as grammar and mechanics. Evaluating learning helps learners with problems like reconsidering global and local features and strategies used to complete the writing task (Goctu, 2017).

As a second language strategy, metacognition is used by effective writers at every stage of the writing process. Highly metacognitive individuals excel in planning, managing information, monitoring, and debugging information. It is also used by learners to self-reflect about their cognition by observing, monitoring, evaluating, and regulating their thought processes during learning (Wong \& Storey, 2006; Wang \& Han, 2017).

Another theory used in this study is the Constructivist Theory by Jean Piaget. This cognitive theory explains that humans cannot be given information; instead, they can construct their learning using experiences and prior knowledge. This theory claims that the learners actively create knowledge and connect to their prior knowledge (Ozdemir \& Aydin, 2015; Ubamos \& Aboy, 2020).

In relation with language learning, language strategies play a vital role in the learning of an individual. The constructivism theory states that language and intellectual skills should be maximized (Epcacan, 2014). Language and learning are inseparably connected (Arslan, 2007; Epcacan, 2014). The text should be used to teach skills to the students.

Specifically, the metacognitive strategies are among the most important in second language learning, especially in writing competence development, since writing is considered to be a difficult task (Safa, 2018). Using these strategies, students have the avenue to construct ideas through planning, self-engagement, and assessment of work. Learners can get confused with all the rules, 
vocabulary, and writing systems; however, they can use the metacognitive strategy to identify their schemata and connect this to the new material by paying more attention to specific details and focusing more on comprehension. Research explains that students who use their metacognitive skills in writing have good academic performance because they can express their thoughts and are also able to communicate with others effectively. On the basis of these points, this study presumes that metacognitive strategies and writing competence are linked with each other.

\subsection{Methods}

This study used descriptive-comparative and correlational research designs. The descriptivecomparative method was used to describe and compare mainly the extent of use of metacognitive strategies and the level of competence in writing of Grade 11 students. The correlational design was utilized to determine whether there is a relationship between students' extent of use of metacognitive strategies and their level of writing competence.

The respondents were the Grade 11 students officially enrolled during the second semester of the school year 2018-2019 of a national high school. A researcher-made survey questionnaire and a test questionnaire were utilized to determine the relationship between the metacognitive strategies and writing competence of Grade 11 students. The research instrument is divided into three parts. The questionnaire was evaluated by English teachers who are experts in teaching English as Second Language and writing. The validity index of the instrument is 3.66 out of 4 . The reliability of the questionnaire established through Cronbach's Alpha is 0.941 or $94.1 \%$, which means that the questionnaire is reliable.

In gathering the data, the researcher sent a letter to the principal and the assistant principal of the selected national high school seeking their permission to administer the study in the school and use the students as respondents. As soon as the principal and the assistant principal approved the request, the researcher reproduced the questionnaires. The researcher set a date for the conduct of the study. On the day prior to the conduct of the study, the researcher gave them an orientation.

During the test administration, the researcher informed the students that they are the respondents of the study. To make the students feel comfortable, the researcher explained the objectives and the benefits of the research. After this, the researcher distributed the instrument to the students and instructed them to accomplish the three parts completely. The students were given one hour and a half $(1 / 2)$ to answer. During the test, the researcher made herself available to clarify any concerns of the students. The accomplished questionnaires were collected soon after each student accomplished the task. The participants were reassured that the data they would give in the questionnaire, including their answers, would be dealt with strict confidentiality.

The data were analyzed and interpreted by applying the appropriate statistical tools. To determine the extent of use of the metacognitive strategies and the level of competence in writing of the Grade 11 students, descriptive analysis using the mean was done. To determine whether or not a significant difference exists in the extent of use of metacognitive strategies and the level of writing competence of Grade 11 students, the comparative analysis using T-test for independent samples, One-way ANOVA and Scheffe test was done. To ascertain if there exists a significant relationship between the extent of use of metacognitive strategies and the level of writing competence of the Grade 11 students, the correlational analysis using Pearson $r$ was done.

\subsection{Results and Discussion}

\section{Extent of the use of the metacognitive strategies}

Table 1 shows that the extent of use of the metacognitive strategies of the Grade 11 students of a national high school, when taken as a whole, is moderate $(M=3.37, S D=0.74)$. The results also show that both sexes have a different extent of use of the metacognitive strategies where the females $(M=3.41, S D=0.72)$ outperformed males $(M=3.33, S D=0.75)$. In terms of family monthly income, the students with high family monthly income performed better using the strategies $(M=$ $3.45, S D=0.75)$ than students with low family monthly income $(M=3.33, S D=0.73)$. In terms of parents' educational status, students whose parents have elementary $(M=3.37, S D=0.73)$ and high school education moderately used the strategies $(M=3.24, S D=0.76)$, while those students whose parents have college $(M=3.58, S D=0.68)$ and postgraduate education use the strategies to a high extent $(M=3.50, S D=0.65)$. In terms of academic performance, the satisfactory $(M=3.17, S D=0.75)$ 
and fairly satisfactory $(M=3.00, S D=0.71)$ students have a moderate extent of use of the strategies. In contrast, outstanding $(M=3.92, S D=0.53)$ and very satisfactory students have a high extent of use of metacognitive strategies $(M=3.58, S D=0.63)$.

The moderate result, as a whole, means that the student-respondents apply and use the strategies half of the time. This result implies that when they have the idea of the strategy, they enhance their writing ability through self-regulation. Moreover, students can regulate their use of approaches vis-avis to what and how they know, and why and when they should apply the knowledge to understand learning and thinking about thinking (Cer, 2019).

The results according to sex revealed that females apply the strategy more than half of the time when they accomplish a writing task while males only apply the strategies half of the time when accomplishing a writing task. These data suggest that gender can influence the use of metacognition. Females tend to use the strategies more often than males do; consequently, they excel in classroom activities. They are also more active and strategic than males since they use only the strategies to quickly accomplish the task. At the same time, the former is more profound when it comes to the use of strategies in writing (Bembenutty, 2007; Callan et al., 2016).

These data further suggest that the challenges that come with having a low family monthly income affect the students' use of strategies since they use and apply the strategies only half of the time when accomplishing a writing task. However, students who belong to the family with high monthly income use and apply the strategies more than half of the time. This reflects that an individual's economic condition affects his learning, specifically in language learning and in the use of the strategies (Callan et al., 2016).

Regarding parents' educational status, students with higher educational attainment tend to apply the strategies more than those with lower educational attainment when accomplishing a writing task. The findings suggest that the higher the parents' educational background, the higher the motivation and support they can give to their children (Gutman et al., 2003; Santos \&Primi, 2014), thus, making their children more academically equipped.

Based on academic performance, students who excel in academics have good metacognitive skills. The academically satisfactory and fairly satisfactory students' moderate extent of use of the strategies and the outstanding and very satisfactory students' high extent of use of metacognitive strategies suggest that the use of metacognitive strategies could be a predictor of academic success (Narang \& Saini, 2013). Furthermore, the positive influence of the training of the metacognitive strategies can yield positive results and improve academic performance and metacognitive abilities (Abdellah, 2015). Students who use metacognition can effectively design their plan for learning and monitor and evaluate their effectiveness.

Table 1. Extent of the use of the metacognitive strategies of the students

\begin{tabular}{|c|c|c|c|c|c|c|c|c|c|c|c|c|}
\hline \multirow[t]{2}{*}{ Variable } & \multicolumn{3}{|c|}{$\begin{array}{l}\text { Planning and } \\
\text { Arranging }\end{array}$} & \multicolumn{3}{|c|}{ Centering } & \multicolumn{3}{|c|}{ Evaluating } & \multicolumn{3}{|c|}{$\begin{array}{l}\text { Metacognitive } \\
\text { Strategies }\end{array}$} \\
\hline & $M$ & SD & Int & $M$ & SD & Int & $M$ & SD & Int & $M$ & SD & Int \\
\hline \multicolumn{13}{|l|}{ Sex } \\
\hline Male & 3.29 & 0.83 & $M E$ & 3.38 & 0.77 & $M E$ & 3.31 & 0.78 & $M E$ & 3.33 & 0.75 & ME \\
\hline Female & 3.45 & 0.72 & $\mathrm{HE}$ & 3.41 & 0.81 & $\mathrm{HE}$ & 3.37 & 0.79 & $M E$ & 3.41 & 0.72 & $\mathrm{HE}$ \\
\hline \multicolumn{13}{|l|}{ Income } \\
\hline Higher & 3.47 & 0.81 & $\mathrm{HE}$ & 3.48 & 0.79 & $\mathrm{HE}$ & 3.40 & 0.79 & ME & 3.45 & 0.75 & $\mathrm{HE}$ \\
\hline Lower & 3.32 & 0.76 & $M E$ & 3.35 & 0.79 & ME & 3.31 & 0.78 & ME & 3.33 & 0.73 & ME \\
\hline \multicolumn{13}{|c|}{ Parents Educational Attainment } \\
\hline Elementary & 3.31 & 0.82 & $M E$ & 3.40 & 0.78 & $M E$ & 3.39 & 0.76 & $M E$ & 3.37 & 0.73 & ME \\
\hline High School & 3.26 & 0.78 & $M E$ & 3.26 & 0.82 & $M E$ & 3.19 & 0.80 & $M E$ & 3.24 & 0.76 & ME \\
\hline College & 3.59 & 0.73 & $\mathrm{HE}$ & 3.59 & 0.71 & $\mathrm{HE}$ & 3.55 & 0.74 & $\mathrm{HE}$ & 3.58 & 0.68 & $\mathrm{HE}$ \\
\hline Post Graduate & 3.36 & 0.77 & ME & 3.63 & 0.71 & $\mathrm{HE}$ & 3.51 & 0.63 & $\mathrm{HE}$ & 3.50 & 0.65 & $\mathrm{HE}$ \\
\hline \multicolumn{13}{|c|}{ Academic Performance } \\
\hline Fairly Satisfactory & 2.93 & 0.77 & $M E$ & 3.05 & 0.80 & ME & 3.04 & 0.70 & ME & 3.00 & 0.71 & ME \\
\hline Satisfactory & 3.20 & 0.79 & $M E$ & 3.19 & 0.78 & ME & 3.11 & 0.79 & ME & 3.17 & 0.75 & ME \\
\hline Very Satisfactory & 3.60 & 0.66 & $\mathrm{HE}$ & 3.60 & 0.70 & $\mathrm{HE}$ & 3.54 & 0.72 & $\mathrm{HE}$ & 3.58 & 0.63 & $\mathrm{HE}$ \\
\hline Outstanding & 3.88 & 0.60 & $\mathrm{HE}$ & 3.95 & 0.62 & $\mathrm{HE}$ & 3.92 & 0.58 & $\mathrm{HE}$ & 3.92 & 0.53 & $\mathrm{HE}$ \\
\hline As a Whole & 3.37 & 0.78 & $M E$ & 3.39 & 0.79 & ME & 3.34 & 0.78 & $M E$ & 3.37 & 0.74 & ME \\
\hline
\end{tabular}

Note: $\mathrm{ME}=$ Mocerate Extent, $\mathrm{Hi}=\mathrm{HE}$ 


\section{Level of writing competence}

Table 2 shows that the students' writing competence is average when taken as a whole $(M=49.95$, $S D=26.78)$. The results suggest that they establish the essential writing skills and do not view writing as a mechanical process. Rather, they view it as a craft that uses understanding, thinking, developing, and producing skills. Competence in this skill enables individuals to excel in whatever field they choose. It contributes to developing other skills and has been used to express feelings and thoughts and communicate information (Mone, 2011).

In terms of sex, although both sexes have the same average writing competence, females $(M=52.37, S D=25.76)$ performed slightly better than males $(M=47.49, S D=27.65)$. The results imply that learners are different from each otherlinguistically (Pajares et al., 2006). Females employ higher writing efficiency, have stronger motivation, and can use language strategies better than males do(Liu, 2015).

In addition, regardless of family factors, including socioeconomic status and parents' educational attainment, students have average writing competence, which means that they can have the essential skills in writing since they are exposed to the same language activities. Surprisingly, the results contradict the concept that family factors such as socioeconomic status affect an individual's writing competence. It is always concluded that economically challenged communities have the lowest or deficient writing competencies (Dela Sena, 2003 cited in Araya, 2006).

Students' level of writing competence differs when they are grouped according to their academic performance because outstanding students have high writing competence $(M=75.19, S D=18.80)$, which means that they apply the essential skills in writing, both very satisfactory $(M=59.52, S D=24.07)$ and satisfactory students $(M=40.85, S D=23.08)$ got an average writing competence. Low-performing students got low writing competence $(M=33.82, S D=24.83)$, which means they have minimum writing skills. In short, writing proficiency is connected to academic performance. This skill is assumed to be of substantial influence in connection to the academic success of a student. When students are weak in writing, they may be at risk for their academics (Tan, 2011; Safa, 2018).

Table 2. Level of writing competence of the students

\begin{tabular}{|c|c|c|c|}
\hline Variable & M & SD & Interpretation \\
\hline \multicolumn{4}{|l|}{ Sex } \\
\hline Male & 47.49 & 27.65 & Average \\
\hline Female & 52.37 & 25.76 & Average \\
\hline \multicolumn{4}{|l|}{ Income } \\
\hline Higher & 52.53 & 27.52 & Average \\
\hline Lower & 48.80 & 26.43 & Average \\
\hline \multicolumn{4}{|c|}{ Parents Educational Attainment } \\
\hline Elementary & 43.24 & 27.25 & Average \\
\hline High School & 47.18 & 26.06 & Average \\
\hline College & 56.57 & 26.92 & Average \\
\hline Post Graduate & 55.96 & 26.38 & Average \\
\hline \multicolumn{4}{|c|}{ Academic Performance } \\
\hline Fairly Satisfactory & 33.82 & 24.83 & Low \\
\hline Satisfactory & 40.85 & 23.08 & Average \\
\hline Very Satisfactory & 59.52 & 24.07 & Average \\
\hline Outstanding & 75.19 & 18.80 & High \\
\hline As a Whole & 49.95 & 26.78 & Average \\
\hline
\end{tabular}




\section{Difference in the extent of use of metacognitive strategies}

Table 3.A reveals no significant difference in the use of metacognitive strategies ( $t=0.954$, $p$-value $=0.341$ ) between the male and the female students. Similarly, based on family monthly income, no significant difference was also noted $(t=1.313$, $p$-value $=0.190)$.

Table 3.B shows that when students are categorized according to their parents' educational status, there is a significant difference between the categories $(F=4.536, p$-value $=0.004)$. Post hoc test revealed that students whose parents are college graduates rated significantly higher than students whose parents are high school graduates.

Table 3.C shows that when students are categorized according to academic performance, there is a significant difference between the categories. $(F=16.136, p$-value $=0.00)$. The post hoc test revealed that very satisfactory and outstanding students rated significantly higher than the fairly satisfactory and satisfactory students.

The categories for sex and family income do not affect the use and application of the metacognitive strategies of Grade 11 students of a selected high school. On the other hand, there is a significant difference in parents' educational status and academic performance. These suggest that the students' use and application of the metacognitive strategies are influenced by their parents' educational attainment, especially the mother. Moreover, when parents are educated, they are active in monitoring their children's progress and academic performance in school. The motivation to study and the use of strategies first come from the household and the family (Gutman et al., 2003; Santos \& Primi 2014).

Furthermore, the results show a significant difference in the extent of the use of metacognitive strategies when they are grouped according to academic performance. This implies that metacognition is a predictor of academic success. Learners who excel academically also know how to think critically. Students who have good metacognitive skills have good academic performance, while students who have poor metacognitive skills also have poor academic performance (Al-Jarrah \& Obeidat, 2011; Narang \& Saini, 2013).

Table $3 A$. Difference in the extent of use of the metacognitive strategies according to sex and income

\begin{tabular}{|c|c|c|c|c|c|c|c|c|c|c|}
\hline \multirow{2}{*}{ Variable } & \multicolumn{2}{|c|}{ Sex } & \multirow[b]{2}{*}{$t$} & \multirow{2}{*}{ df } & \multirow[b]{2}{*}{$\mathrm{p}$} & \multicolumn{2}{|c|}{ Income } & \multirow[b]{2}{*}{$t$} & \multirow[b]{2}{*}{ df } & \multirow[b]{2}{*}{$p$} \\
\hline & Male & Female & & & & Higher & Lower & & & \\
\hline $\begin{array}{l}\text { Planning and } \\
\text { Arranging of Learning }\end{array}$ & $\begin{array}{c}3.29 \\
(0.83)\end{array}$ & $\begin{array}{c}3.45 \\
(0.72)\end{array}$ & 1.747 & 301 & 0.082 & $\begin{array}{c}3.47 \\
(0.81)\end{array}$ & $\begin{array}{c}3.32 \\
(0.76)\end{array}$ & 1.493 & 301 & 0.136 \\
\hline Centering of Learning & $\begin{array}{c}3.38 \\
(0.77) \\
\end{array}$ & $\begin{array}{c}3.41 \\
(0.81) \\
\end{array}$ & 0.262 & 301 & 0.793 & $\begin{array}{c}3.48 \\
(0.79)\end{array}$ & $\begin{array}{c}3.35 \\
(0.79) \\
\end{array}$ & 1.322 & 301 & 0.187 \\
\hline Evaluating of Learning & $\begin{array}{c}3.31 \\
(0.78)\end{array}$ & $\begin{array}{c}3.37 \\
(0.79)\end{array}$ & 0.703 & 301 & 0.483 & $\begin{array}{c}3.40 \\
(0.79)\end{array}$ & $\begin{array}{c}3.31 \\
(0.78)\end{array}$ & 0.893 & 301 & 0.373 \\
\hline $\begin{array}{l}\text { Metacognitive } \\
\text { Strategies }\end{array}$ & $\begin{array}{c}3.33 \\
(0.75)\end{array}$ & $\begin{array}{c}3.41 \\
(0.72)\end{array}$ & 0.954 & 301 & 0.341 & $\begin{array}{c}3.45 \\
(0.75)\end{array}$ & $\begin{array}{c}3.33 \\
(0.73)\end{array}$ & 1.313 & 301 & 0.190 \\
\hline
\end{tabular}

Note: the difference is significant when $p \leq 0.05$

Table 3B. Difference in the extent of use of the metacognitive strategies according to parents' educational attainment

\begin{tabular}{|c|c|c|c|c|c|c|c|}
\hline \multirow[b]{2}{*}{ Variable } & \multicolumn{4}{|c|}{ Parents Educational Attainment } & \multirow[b]{2}{*}{$\mathrm{F}$} & \multirow{2}{*}{ df } & \multirow[b]{2}{*}{$\mathrm{p}$} \\
\hline & Elementary & High School & College & Post Graduate & & & \\
\hline \multirow{2}{*}{$\begin{array}{l}\text { Metacognitive } \\
\text { Strategies }\end{array}$} & 3.37 & 3.24 & 3.58 & 3.50 & \multirow[b]{2}{*}{4.326} & \multirow{2}{*}{3,209} & \multirow[b]{2}{*}{0.005} \\
\hline & $(0.73)$ & $(0.76)$ & $(0.68)$ & $(0.65)$ & & & \\
\hline \multirow{2}{*}{$\begin{array}{l}\text { Planning and } \\
\text { Arranging of Learning }\end{array}$} & 3.31 & 3.26 & 3.59 & 3.36 & \multirow{2}{*}{3.585} & \multirow{2}{*}{3,209} & \multirow{2}{*}{0.014} \\
\hline & $(0.82)$ & $(0.78)$ & $(0.73)$ & $(0.77)$ & & & \\
\hline \multirow{2}{*}{ Centering of Learning } & 3.40 & 3.26 & 3.59 & 3.63 & \multirow{2}{*}{3.858} & \multirow[b]{2}{*}{3,209} & \multirow{2}{*}{0.010} \\
\hline & $(0.78)$ & $(0.82)$ & $(0.71)$ & $(0.71)$ & & & \\
\hline \multirow{2}{*}{ Evaluating of Learning } & 3.39 & 3.19 & 3.55 & 3.51 & \multirow{2}{*}{4.536} & \multirow{2}{*}{3,209} & \multirow{2}{*}{0.004} \\
\hline & $(0.76)$ & $(0.80)$ & $(0.74)$ & $(0.63)$ & & & \\
\hline
\end{tabular}

Note: the difference is significant when $\mathrm{p} \leq 0.05$ 
Philippine Social Science Journal

Table 3C. Difference in the extent of use of the metacognitive strategies according to academic performance

\begin{tabular}{|c|c|c|c|c|c|c|c|}
\hline \multirow[b]{2}{*}{ Variable } & \multicolumn{4}{|c|}{ Academic Performance } & \multirow[b]{2}{*}{$F$} & \multirow[b]{2}{*}{ df } & \multirow[b]{2}{*}{$\mathrm{p}$} \\
\hline & $\begin{array}{c}\text { Fairly } \\
\text { Satisfactory }\end{array}$ & Satisfactory & $\begin{array}{c}\text { Very } \\
\text { Satisfactory }\end{array}$ & Outstanding & & & \\
\hline \multirow{2}{*}{$\begin{array}{l}\text { Metacognitive } \\
\text { Strategies }\end{array}$} & 3.00 & 3.17 & 3.58 & 3.92 & \multirow{2}{*}{18.773} & \multirow{2}{*}{3,209} & \multirow{2}{*}{0.000} \\
\hline & $(0.71)$ & $(0.75)$ & $(0.63)$ & $(0.53)$ & & & \\
\hline \multirow{2}{*}{$\begin{array}{l}\text { Planning and } \\
\text { Arranging of Learning }\end{array}$} & 2.93 & 3.20 & 3.60 & 3.88 & \multirow{2}{*}{17.710} & \multirow{2}{*}{3,209} & \multirow{2}{*}{0.000} \\
\hline & $(0.77)$ & $(0.79)$ & $(0.66)$ & $(0.60)$ & & & \\
\hline \multirow{2}{*}{ Centering of Learning } & 3.05 & 3.19 & 3.60 & 3.95 & \multirow{2}{*}{15.626} & \multirow{2}{*}{3,209} & \multirow{2}{*}{0.000} \\
\hline & $(0.80)$ & $(0.78)$ & $(0.70)$ & $(0.62)$ & & & \\
\hline \multirow{2}{*}{ Evaluating of Learning } & 3.04 & 3.11 & 3.54 & 3.92 & \multirow{2}{*}{16.136} & \multirow{2}{*}{3,209} & \multirow{2}{*}{0.000} \\
\hline & $(0.70)$ & $(0.79)$ & $(0.72)$ & $(0.58)$ & & & \\
\hline
\end{tabular}

Note: the difference is significant when $p \leq 0.05$

\section{Differences in the level of writing competence}

Table 4.A shows no significant difference in the level of writing competence between the male and the female students $(t=1.588, p$-value $=0.113)$. Similarly, based on family monthly income, no significant difference was also noted between $(t=1.122$, $p$-vale $=0.263$ ) students whose family monthly income is greater than the average income and those whose income was less than the average income. These demographics do not affect the learners' writing competence as long as they are exposed to the same writing and language activities.

However, Table 4.B shows that there is a significant difference in the level of writing competence when students are categorized according to their parents' educational status ( $F=3.455, p$-value $=0.017)$ and academic performance $(F=32.873, p=0.000)$. Post hoc test revealed that students whose parents are college graduates have significantly higher writing competence than students whose parents are elementary and high school graduates. In terms of academic performance, outstanding students have significantly higher writing competence than any other students.

Table 4A. Difference in the level of writing competence according to sex and family income

\begin{tabular}{|c|c|c|c|c|c|}
\hline \multirow{2}{*}{ Variable } & \multicolumn{2}{|c|}{ Sex } & \multirow[t]{2}{*}{$t$} & \multirow[t]{2}{*}{ df } & \multirow[t]{2}{*}{$p$} \\
\hline & Male & Female & & & \\
\hline \multirow{6}{*}{ Writing } & 47.49 & 52.37 & 1.588 & 301 & 0.113 \\
\hline & (27.65) & $(25.76)$ & & & \\
\hline & \multicolumn{2}{|c|}{ Income } & $t$ & $d f$ & $p$ \\
\hline & Higher & Lower & & & \\
\hline & 52.53 & 48.80 & 1.122 & 301 & 0.263 \\
\hline & (27.52) & $(26.43)$ & & & \\
\hline
\end{tabular}

Note: the difference is significant when $p \leq 0.05$

Table 4B. Difference in the level of writing competence according to parents' educational attainment and academic performance

\begin{tabular}{|c|c|c|c|c|c|c|}
\hline \multicolumn{4}{|c|}{ Parents Educational Attainment } & \multirow[t]{2}{*}{$\mathrm{F}$} & \multirow[t]{2}{*}{ df } & \multirow[t]{2}{*}{$p$} \\
\hline Elementary & High School & College & Post Graduate & & & \\
\hline 43.24 & 47.18 & 56.57 & 55.96 & 3.455 & 3,299 & 0.017 \\
\hline$(27.25)$ & (26.06) & (26.92) & (26.38) & & & \\
\hline Academic Performance & & & & $F$ & df & $\mathrm{p}$ \\
\hline Fairly Satisfactory & Satisfactory & Very Satisfactory & Outstanding & & & \\
\hline 33.82 & 40.85 & 59.52 & 75.19 & 32.873 & 3,299 & 0.000 \\
\hline$(24.83)$ & $(23.08)$ & $(24.07)$ & $(18.80)$ & & & \\
\hline
\end{tabular}

Note: the difference is significant when $p \leq 0.05$ 


\section{Relationship between metacognitive strategies and writing competence}

Table 5 shows that there is a significant correlation between metacognitive strategies and the writing competence of students. This result means that the use of metacognitive strategies affects the students' writing competence.When students know how to plan, center, arrange, and evaluate their learning, they can enhance their writing competence. Consequently, when students lack the usage and application of metacognitive strategies, they may also struggle when accomplishing writing tasks. Furthermore, when learners enter the writing process, they already have the metacognitive knowledge based on their cognitive model for the writing process, which has implications in writing and the written work (Panahandeha, 2014). This helps students become self-knowing, self-directed, and self-managed and activates their thinking (Vandergit\& Goh, 2012).

Table 5. Relationship between the use of the metacognitive strategies and writing competence

\begin{tabular}{|c|c|c|c|}
\hline & & Writing Competence & Metacognitive Strategies \\
\hline \multirow{3}{*}{ Writing Competence } & $\mathrm{r}$ & 1 & $.503^{\star \star}$ \\
\hline & Sig. (2-tailed) & & .000 \\
\hline & $\mathrm{N}$ & 303 & 303 \\
\hline \multirow{3}{*}{$\begin{array}{l}\text { Metacognitive } \\
\text { Strategies }\end{array}$} & r & $.503^{\times x}$ & 1 \\
\hline & Sig. (2-tailed) & .000 & \\
\hline & $\mathrm{N}$ & 303 & 303 \\
\hline
\end{tabular}

$\approx \times$ Correlation is significant at the 0.01 level (2-tailed).

\subsection{Conclusion}

The relationship between the extent of use of the metacognitive strategies and writing competence is evident in the present study results. The extent of the use of metacognitive strategies affects the writing competence of students. When students use the strategies effectively, such as knowinghow to plan, arrange, center, and evaluate their learning process during a writing activity, they tend to apply essential writing skills. On the other hand, when students do not apply the strategy, they may develop only the minimum writing skills.

Accordingly, there is a need for improvement in terms of the extent of using metacognitive strategies and the level of writing competence among the Grade 11 students of the selected national high school. With the clear goal of the Philippine Department of Education's K+12 program for global competitiveness, the students' extent of use of the metacognitive strategies and the student's level of writing competence need to be enhanced by including metacognitive strategies in writing lessons, proper training, instruction, and practice.

Moreover, though there is no significant difference found in the extent of use of the metacognitive strategies and the level of writing competence of students in terms of sex and family monthly income, the influence of the level of education of parents as well as the academic performance of students were found to make a significant difference. This meansthatthe higher the level of parent's education, the higher the extent of use of the metacognitive strategies and their children's writing competence. Consequently, academic performance can be a predictor of the extent of use of the strategies and writing competence. The higher the students' academic performance, the higher is their extent of use of the strategies and level of writing competence.

Lastly, parents' influence plays a major role in enhancing the different skills of learners, including their writing skills. Writing is a thorough mental activity in which one needs to organize thoughts clearly and accordingly before putting them into written form. Therefore, students who have good mental activities and know how to organize their thoughts excel in using this skill.

\section{REFERENCES}

Abdellah, R. (2015). Metacognitive awareness and its relation to academic achievement and teaching performance of pre-service female teachers in Ajman University in UAE. Procedia - Social and Behavioral Sciences 174( 2015 ) $560-567$.

Alameddine, M. M., \& Mirza, H. S. (2016). Teaching academic writing for advanced level grade 10 English. ProcediaSocial and Behavioral Sciences, 232, 209-216. https://doi.org/10.1016/j.sbspro.2016.10.048 
Araya, J. (2006). An error analysis of essays of freshmen English Majors in Iligan City. A Masters Thesis. Graduate School, St. Micheal's College. Iligan City, Philippines.

Bembenutty, H. (2007). Self-regulation of learning and academic delay of gratification: Gender and ethnic differences among college students. Journal of Advanced Academics, 18(4), 586-616. http://dx.doi. org/10.4219/jaa-2007-553.

Callan, G. L., Marchant, G. J., Finch, W. H., \& German, R. L. (2016). Metacognition, strategies, achievement, and demographics: Relationships across countries. Educational Sciences: Theory \& Practice, 16(5). https://doi. org/10.1037/e620232013-001

Cer, E. (2019). The instruction of writing strategies: The effect of the metacognitive strategy on pupils' writing skills in secondary education. SAGE Open, 9(2), 2158244019842681. https://doi.org/10.1177/2158244019842681

Chien, S. C. (2007). The role of Chinese EFL learners' rhetorical strategy use in relation to their achievement in English writing. English Teaching: Practice and Critique, 6(1), 132-150. https://eric.ed.gov/?id=EJ832182

Epçaçan, C. (2014). Examination of texts of secondary school Turkish schoolbooks in terms of constructivism approach. Procedia-Social and Behavioral Sciences, 116, 5105-5114. https://doi.org/10.1016/j. sbspro.2014.01.1082

Farooq, M. S., Uzair-Ul-Hassan, M., \& Wahid, S. (2012). The opinion of second language learners about writing difficulties in the English language. South Asian Studies, 27(1), 183-194. Retrieved from https://search. proquest.com/ docview/1023239824?accountid=34542

Goctu, R. (2017). Metacognitive strategies in academic writing. Journal of Education in Black Sea Region, 2(2), 8-9. https://doi.org/10.31578/jebs.v2i2.44

Gutman, L. M., Sameroff, A. J., \& Cole, R. (2003). Academic growth curve trajectories from the 1st grade to 12thgrade: Effects of multiple social risk factors and preschool child factors. Development Psychology, 39(4), 777---790. http://dx.doi.org/10.1037/0012-1649.39.4.777.

Harris, K. R., Santangelo, T., \& Graham, S. (2008). Self-regulated strategy development in writing: Going beyond NLEs to a more balanced approach. Instructional Science, 36(5-6), 395. https://doi.org/10.1007/s11251-0089062-9

Krashen, S. D. (1981). Bilingual education and second language acquisition theory. Schooling and language minority students: A theoretical framework, 51-79.

Liu, G. (2015). Investigating the English writing strategies used by Chinese senior high school students. Theory and Practice in Language Studies, Vol. 5, No. 4, pp. 844-850, April 2015. http://dx.doi.org/10.17507/tpls.0504.21.

Mone. (2011). Ortaretim kurumlarngilizce dersi retim program. Ankara.

Narang, D., \& Saini, S. (2013). Metacognition and academic performance of rural adolescents. Studies on Home and Community Science, 7(3), 167-175. https://doi.org/10.1080/09737189.2013.11885409

Nosratinia, M., \& Adibifar, S. (2014). The effect of teaching metacognitive strategies on field-dependent and independent Learners' writing. Procedia-Social and Behavioral Sciences, 98, 1390-1399. https://doi. org/10.1016/j.sbspro.2014.03.557

Nguyen, L., \& Gu, Y. (2013). Strategy-based instruction: A learner-focused approach to developing learner autonomy. Language Teaching Research 17 (1) 9-30. Victoria University of Wellington, New Zealand. http:// dx.doi.org/10.1177/1362168812457528.

Oxford, R. (1990). Language learning strategies. New York, 3.

Özdemir, E., \& Aydın, S. (2015). The effects of wikis on motivation in EFL writing. Procedia-Social and Behavioral Sciences, 191, 2359-2363. https://doi.org/10.1016/j.sbspro.2015.04.241

Panahandeh, E. \& Asl, S. (2014). The effect of planning and monitoring metacognitive strategies on Iranian EFL learners' argumentative writing accuracy. Procedia- Social and Behavioral Sciences 98 (2014) 1409-1416.

Pajares, F., et al. (2006). Writing self-efficacy and its relation to gender, writing motivation, and writing competence: a developmental perspective in G. Rijlaarsdam (Series ed) \& P. Boscolo \& S. Hidi (Volumes ed), Studies in Writing. Volume 19, Writing and Motivation (pp. 141-159). Oxford, Elsevier.

Quijano, L. J. T. \& Legaspi, M J. B. (2020). English proficiency and sequencing skills in narrative writing of public high school students. Philippine Social Science Journal, 3(3), 129-141. https://doi.org/10.52006/main.v313.249

Rani, R., \& Govil, P. (2013). Metacognition and its correlates: A study. International Journal of Advancement in Education and Social Sciences, 1(1), 20-25. https://www.homesciencejournal.com/archives/2020/vol6issue2/ PartG/6-2-42-176.pdf

Safa, A. (2018). A brief overview of the key issues in second language writing teaching and research. International Journal of Education \& Literacy Studies ISSN: 2202-9478. www.ijels.aiac.org.au.

Santos, D., \& Primi, R. (2014). Desenvolvimento socioemocional eaprendizado escolar: Uma proposta de mensurac,ão para apoiarpolíticas públicas. São Paulo: Instituto Ayrton Senna.

Tabak, G., \& Topuzkanamis, E. (2014). An analysis of writing dispositions of 6th-grade students in terms of different variables. Online Su bmission, 4(2), 1-11. https://doi.org/10.13054/mije.14.15.4.2

Terogo, I. J. R., Elimino, C. A. C., Tallo, J. P. M., Sacal, J. A., \& Balahadia, C. M. J. E. (2018). Linguistic and sociolinguistic competence of senior high school students. Recoletos Multidisciplinary Research Journal, 6(1). http://doi.org/10.32871/rmrj806.01.03

Ubamos, G. U., \& Aboy, I. G. (2020). Morphemic and Semantic Analyses Skills of Senior High School Students. Philippine Social Science Journal, 2(2), 91-106. https://doi.org/10.52006/main.v2i2.85. 
Ungan, S. (2007). Development of and importance of writing skills. Erciyes University Journal of the Institute of Social Sciences, 23, 461-472.

Vandergrit, L. \& Goh C. (2012). Teaching and learning second language listening: metacognition in action. UK: Taylor and Francis.

Wang, Z. \& Han, F. (2017). Metacognitive knowledge and metacognitive control of writing strategy between highand low-performing Chinese EFL writers. Theory and Practice in Language Studies, Vol. 7, No. 7, pp. 523-532, July 2017 DOI: http://dx.doi.org/10.17507/tpls.0707.04.

\section{Correspondence:}

GLORY ANN L. HACERMIDA

tinkerbellrox109@gmail.com

https://orcid.org/0000-0003-3811-2350

IVY G. ABOY

ivygonzales_aboy@yahoo.com

https://orcid.org/0000-0002-2281-270X 